Volume. 2 Nomor. 2

Periode: Juli - Desember 2018; hal. 106-125

p-ISSN : 2580-1112; e-ISSN : 2655-6669

Copyrighr@2018

Penulis memiliki hak cipta atas artikel ini

Jurnal Ilmiah Keperawatan Orthopedi (JIKO)

journal homepage:

https://ejournal.akperfatmawati.ac.id

\title{
Pengaruh Gaya Hidup Terhadap Kejadian Dm Tipe 2 Di Poliklinik Penyakit Dalam RSPAD Gatot Subroto Jakarta Pusat Tahun 2017
}

\author{
Imam Subiyanto ${ }^{1}$ \\ Akademi Kepera watan RSPAD Gatot Soebroto
}

\begin{abstract}
Abstrak
Prevalensi DM di Indonesia pada tahun 2013 sebesar 2,1\% meningkat dari tahun 2007 yang hanya 1,1\% dan DKI jakarta berada diatas rata-rata prevalensi nasional yaitu 3,0\%. Data DM di RSPAD tahun 2016 merupakan penyakit terbanyak dari 10 penyakit tertinggi (50\%), maka maka perlu dilakukan penelitian tentang hubungan antara gaya hidup dengan kejadian diabetes mellitus tipe 2. Tujuan Penelitian ini untuk mengetahui hubungan antara gaya hidup dengan kejadian DM tipe 2 di poliklinik penyakit dalam RSPAD Gatot Subroto Jakarta Pusat tahun 2017. Jenis penelitian ini adalah studi analitik observasional dengan desain kasus kontrol (case control study). Sampel kasus adalah pasien di Poliklinik Penyakit Dalam RSPAD Gatot Subroto yang terdiaknosa DM tipe 2, sedangkan sampel kontrol adalah pasien di Poliklinik Penyakit Dalam RSPAD Gatot Subroto yang tidak terdiaknosa DM tipe 2. Jumlah sampel terdiri dari 162 kasus dan 162 kontrol. Pengumpulan data menggunakan lembar kuesioner. Analisis data menggunakan uji Chi-square dan regresi logistik berganda. Hasil penelitian menunjukkan bahwa proporsi responden yang berumur $\geq 40$ tahun $(68,8 \%)$, berjenis kelamin perempuan $(49,4 \%)$, berpendidikan rendah $(23,5 \%)$, ada riwayat DM $(41,4 \%)$, aktivitas fisik kurang $(59,0 \%)$, pola makan tidak seimbang $(53,7 \%)$, merokok $(31,2 \%)$ dan obesitas $(41,0 \%)$. Hasil analisis bivariat menunjukan variabel yang berhubungan dengan kejadian DM tipe 2 adalah umur, jenis kelamin, aktivitas fisik, pola makan dan obesitas $(\mathrm{p}<0,05)$. Variabel yang tidak berhubungan dengan kejadian DM tipe 2 adalah pendidikan dan kebiasaan merokok $(\mathrm{p}>0,05)$. Variabel paling berhubungan dengan DM tipe 2 adalah aktivitas fisik (OR 4,727). Disarankan pada masyarakat untuk selalu melakukan aktivitas fisik yang cukup seperti joging, senam aerobik, bersepeda, dll, terutama bagi wanita yang hanya mengerjakan pekerjaan rumah saja. Disarankan untuk selalu menjaga pola makan yang seimbang dengan cara meng konsumsi karbohidrat secukupnya saja dan menerapkan pola makan rendah lemak dan tinggi serat (sayur dan buah).
\end{abstract}

Kata Kunci: DM TIPE 2, Umur, Jenis Kelamin, Aktivitas Fisik, Pola Makan, Obesitas

${ }^{1}$ e-mail: imam.subiyanto@akperrspadjakarta.ac.id 
Pendahuluan

Diabetes Melitus (DM) atau yang umumnya dikenal penyakit kencing manis adalah penyakit metabolisme yang merupakan suatu kumpulan gejala yang timbul pada seseorang karena adanya peningkatan kadar glukosa darah di atas nilai normal. Kencing manis atau DM disebabkan gangguan metabolisme glukosa akibat kekurangan insulin baik secara
absolut maupun relatif. Ada 2 tipe diabetes melitus yaitu diabetes tipe $\mathrm{I} /$ diabetes juvenile yaitu diabetes yang umumnya didapat sejak masa kanak-kanak dan diabetes tipe 2 yaitu diabetes yang didapat setelah dewasa (Kemenkes RI, 2013).

Global status report on non communicable diseases tahun 2014 yang dikeluarkan oleh World Health Organization (WHO) menyatakan bahwa prevalensi DM di seluruh dunia diperkirakan sebesar $9 \%$. Sedangkan proporsi kematian akibat penyakit DM dari seluruh kematian akibat penyakit tidak menular adalah sebesar $4 \%$. Kematian akibat DM terjadi pada negara dengan pendapatan rendah dan menengah dengan proporsi sebesar $80 \%$. Pada Tahun 2030 diperkirakan DM menempati urutan ke-7 penyebab kematian di dunia (WHO, 2014).

International Diabetes Federation (IDF) melalui Diabetes Atlas tahun 2015 diperkirakan sekitar 415 juta orang dewasa di dunia menyandang diabetes melitus pada tahun 2015, pada 2040 ini akan meningkat menjadi sebesar 640 juta. Menurut estimasi IDF (2015) 8,8\% penduduk di seluruh dunia mengalami DM, prevalensi ini meningkat dari tahun 2014 yaitu $8,3 \%$ dan diprediksikan pada tahun 2040 prevalensi DM akan meningkat menjadi 10,4\%. Bahkan, Indonesia merupakan negara terbesar ketujuh di dunia setelah RRC, India, USA, Brazil, Rusia dan Meksiko melitus sebanyak 10 juta orang pada tahun 2015. Menurut data Riskesdas 2013, prevalensi nasional diabetes melitus di Indonesia untuk usia 15 tahun $\mathrm{ke}$ atas sebesar 6,9\% (IDF, 2015).
Menurut

Persatuan

Ahli

Endokrinologi Indonesia (PERKENI)

kriteria seseorang menderita DM adalah: 1) Kadar glukosa darah sewaktu sebesar $\geq 200$ $\mathrm{mg} / \mathrm{dL}$ yang diambil melalui plasma vena atau $\geq 200 \mathrm{mg} / \mathrm{dL}$ yang diambil melalui darah kapiler ; dan 2) Kadar glukosa darah puasa sebesar $\geq 126 \mathrm{mg} / \mathrm{dL}$ yang diambil melalui plasma darah dan $\geq 100 \mathrm{mg} / \mathrm{dL}$ yang diambil melalui darah kapiler (PERKENI, 2011).

Data Hasil Riset Kesehatan Dasar (Riskesdas) tahun 2013 menunjukkan peningkatan prevalensi DM (terdiagnosis dokter atau gejala) dibanding tahun 2007 pada kelompok usia $\geq 15$ tahun. Tahun 2007, prevalensi DM sebesar 1,1\% sedangkan tahun 2013 menjadi 2,1\% di seluruh Indonesia. Sementara prevalensi DM di Indonesia yang terdiagnosis dokter adalah sebesar $1,5 \%$ pada tahun 2013. Prevalensi DM type 2 pada kelompok usia $\geq$ 15 tahun di provinsi DKI Jakarta berada di atas rata-rata prevalensi nasional, yakni sebesar 2,5\% (berdasarkan diagnosis dokter) dan sebesar 3,0\% (berdasarkan diagnosa dokter). Prevalensi DM tipe 2 di kota Jakarta Pusat menurut data profil kesehatan pada tahun 2009 mencapai 4,8\% (Riskesdas, 2013).

Penyebab DM tidak semata-mata oleh faktor tunggal tetapi hasil dari sebuah kombinasi berbagai faktor risiko. Selain faktor genetik dan aspek sosio-demografi, faktor lingkungan yang meliputi gaya hidup merupakan salah satu faktor penyebab terjadinya DM. Faktor gaya hidup meliputi pola makan, kurangnya aktivitas fisik, kebiasaan merokok, konsumsi alkohol, kurangnya istirahat (Sluik et al, 2013). American Diabetes Association (ADA), faktor risiko DM tipe 2 adalah sebagai berikut: usia $\geq 45$ tahun, overweight atau IMT $>25 \mathrm{~kg} / \mathrm{m}^{2}$, riwayat penyakit diabetes pada keluarga, gaya hidup kurang bergerak, ras/etnis, riwayat DM gestatsional atau pernah melahirkan bayi dengan berat $>4 \mathrm{~kg}$, hipertensi (> 140/90 mmHg), level HDL Kolesterol $<35 \mathrm{mg} / \mathrm{dL}$ dan riwayat penyakit kardiovaskular. 
Berdasarkan data rekapitulasi Kasus adalah penderita Diabetes penyakit di RSPAD Gatot Subroto, DM Melitus usia $\geq 15$ tahun selama tahun 2016 merupakan penyakit tertinggi dalam 10 yang didapatkan dari Rekam Medis besar penyakit pada poliklinik penyakit Poliklinik penyakit dalam RSPAD Gatot dalam 3 tahun terakhir. Pada tahun 2016 Subroto. Kontrol adalah selain penderita jumlah penyakit DM sebanyak 15240 (50\%) DM tipe 2 usia $\geq 15$ tahun yang datang dari 10 besar penyakit, persentase ini berobat ke Poliklinik Penyakit Dalam meningkat dari tahun $2015(37,6 \%)$.

RSPAD Gatot Subroto

Atas dasar hal tersebut diatas Besar sampel dihitung dengan peneliti berasumsi bahwa perlu dilakukan menggunakan rusmus besar sampel uji penelitian tentang "pengaruh gaya hidup hipotesis perbedaan 2 proporsi. Jumlah terhadap kejadian diabetes mellitus (DM) sampel minimal untuk kasus sebanyak 162. tipe 2 di poliklinik penyakit dalam RSPAD Perbandingan sampel yang digunakan 1:1, Gatot Subroto Jakarta Pusat tahun 2017. sehingga untuk kelompok kasus 162 dan

Tujuan Penelitian ini adalah untuk kontrol 162, maka total dari sampel yang mengetahui pengaruh antara gaya hidup digunakan baik kelompok kasus dan terhadap kejadian DM tipe 2 di poliklinik kelompok control sebanyak 324 responden. penyakit dalam RSPAD Gatot Subroto Teknik pengambilan sampel yang Jakarta Pusat tahun 2017.

\section{Metode Penelitian}

Jenis penelitian yang digunakan adalah studi analitik observasional dengan desain kasus control (case control study).

Pendekatan yang digunakan adalah pendekatan retrospektif dimana efek diidentifikasi pada saat ini kemudian faktor risiko diidentifikasi terjadinya pada waktu yang lalu.

Populasi kasus dalam penelitian ini adalah seluruh pasien penderita DM tipe 2 yang terdaftar dari tahun 2016 dan berkunjung ke Poliklinik Penyakit Dalam RSPAD Gatot Subroto Tahun 2017. Populasi Kontrol adalah seluruh parien yang tidak menderita DM yang berkunjung ke Poliklinik Penyakit Dalam RSPAD Gatot Subroto Tahun 2017. digunakan untuk sampel kasus dan kontrol adalah purposive sampling yang diambil berdasarkan data rekam medik yang memenuhi kriteria inklusi dan eksklusi

\section{Hasil Penelitian}

\section{Analisis Univariat}

Variabel Dependen

Tabel 1 Distribusi Responden Menurut

Kejadian DM tipe 2 Dan Kontrol Di

Poliklinik Penyakit Dalam Rspad Gatot

Subroto Jakarta Pusat Tahun 2017

\begin{tabular}{|c|c|c|}
\hline $\begin{array}{c}\text { Kejadian } \\
\text { DM tipe } 2\end{array}$ & Jumlah & $\begin{array}{c}\text { Persentasi } \\
(\%)\end{array}$ \\
\hline Kasus & 162 & 50 \\
Kontrol & 162 & 50 \\
\hline Total & 324 & 100 \\
\hline
\end{tabular}

Berdasarkan tabel diatas terlihat bahwa ada 162 kasus dan ada 162 kontrol.

Variabel Independen

Umur

Tabel 2 Distribusi Frekuensi Umur Pada Kasus Dan Kontrol Di Poliklinik Penyakit Dalam RSPAD Gatot Subroto Jakarta Pusat Tahun 2017

\begin{tabular}{|c|c|c|c|c|c|c|}
\hline \multirow{2}{*}{ Umur } & \multicolumn{2}{|c|}{ Kasus } & \multicolumn{2}{c|}{ Kontrol } & \multicolumn{2}{c|}{ Total } \\
\cline { 2 - 7 } & $\mathrm{n}$ & $\%$ & $\mathrm{n}$ & $\%$ & $\mathrm{n}$ & $\%$ \\
\hline 240 Tahun & 136 & 84,0 & 87 & 53,7 & 223 & 68,8 \\
<40 Tahun & 26 & 16,0 & 75 & 46,3 & 101 & 31,2 \\
\hline Total & 162 & 100 & 162 & 100 & 324 & 100 \\
\hline
\end{tabular}

Berdasarkan tabel 2 diatas terlihat pada umur $\geq 40$ tahun kelompok kontrol bahwa proporsi kejadian DM tipe 2 pada sebanyak $87(53,7 \%)$, sedangkan umur $<40$ umur $\geq 40$ tahun kelompok kasus sebanyak tahun sebanyak 75 (46,3\%). Penderita DM $136(84,0 \%)$, sedangkan umur $<40$ tahun tipe 2 usia $\geq 40$ tahun lebih banyak pada sebanyak $26(16,0 \%)$. Kejadian DM tipe 2 
kelompok kasus dari pada kelompok Jenis Kelamin kontrol.

Tabel 3 Distribusi Frekuensi Jenis Kelamin Pada Kasus Dan Kontrol Di Poliklinik

Penyakit Dalam RSPAD Gatot Subroto Jakarta Pusat Tahun 2017

\begin{tabular}{|c|c|c|c|c|c|c|}
\hline \multirow{2}{*}{ Jenis Kelamin } & \multicolumn{2}{|c|}{ Kasus } & \multicolumn{2}{c|}{ Kontrol } & \multicolumn{2}{c|}{ Total } \\
\cline { 2 - 7 } & $\mathrm{n}$ & $\%$ & $\mathrm{n}$ & $\%$ & $\mathrm{n}$ & $\%$ \\
\hline Perempuan & 92 & 56,8 & 68 & 42,0 & 160 & 49,4 \\
Laki-Laki & 70 & 43,2 & 94 & 58,0 & 164 & 50,6 \\
\hline
\end{tabular}

Berdasarkan tabel 3 diatas terlihat bahwa kontrol sebanyak $68(42,0 \%)$, sedangkan proporsi kejadian DM tipe 2 pada jenis laki-laki sebanyak 94 (58,0\%). Penderita kelamin perempuan kelompok kasus DM tipe 2 yang berjenis kelamin perempuan sebanyak 92 (56,8\%), sedangkan laki-laki lebih banyak pada kelompok kasus (92) dari sebanyak 70 (43,2\%). Kejadian DM tipe 2 pada kelompok kontrol (68).

pada jenis kelamin perempuan kelompok Pendidikan

Tabel 4 Distribusi Frekuensi Pendidikan Pada Kasus Dan Kontrol Di Poliklinik Penyakit Dalam RSPAD Gatot Subroto Jakarta Pusat Tahun 2017

\begin{tabular}{|c|c|c|c|c|c|c|}
\hline \multirow{2}{*}{ Pendidikan } & \multicolumn{2}{|c|}{ Kasus } & \multicolumn{2}{c|}{ Kontrol } & \multicolumn{2}{c|}{ Total } \\
\cline { 2 - 7 } & $\mathrm{n}$ & $\%$ & $\mathrm{n}$ & $\%$ & $\mathrm{n}$ & $\%$ \\
\hline Rendah & 40 & 24,7 & 33 & 20,4 & 76 & 23,5 \\
Tinggi & 122 & 75,3 & 129 & 79,6 & 248 & 76,5 \\
\hline
\end{tabular}

Berdasarkan tabel 4 diatas terlihat kontrol sebanyak 33 (20,4\%), sedangkan bahwa proporsi kejadian DM tipe 2 pada pendidikan tinggi sebanyak $129(79,6 \%)$. pendidikan rendah kelompok kasus Penderita DM tipe 2 yang pendidikan sebanyak 40 (24,7\%), sedangkan pendidikan rendah lebih banyak pada kelompok kasus tinggi sebanyak 122 (75,3\%). Kejadian DM (40) dari pada kelompok kontrol (33).

tipe 2 pada pendidikan rendah kelompok Riwayat DM

Tabel 5 Distribusi Frekuensi Riwayat DM Pada Kasus Dan Kontrol Di Poliklinik Penyakit Dalam RSPAD Gatot Subroto Jakarta Pusat Tahun 2017

\begin{tabular}{|c|c|c|c|c|c|c|}
\hline \multirow{2}{*}{ Riwayat DM } & \multicolumn{2}{|c|}{ Kasus } & \multicolumn{2}{c|}{ Kontrol } & \multicolumn{2}{c|}{ Total } \\
\cline { 2 - 7 } & $\mathrm{n}$ & $\%$ & $\mathrm{n}$ & $\%$ & $\mathrm{n}$ & $\%$ \\
\hline Ada & 75 & 46,3 & 59 & 36,4 & 134 & 41,4 \\
Tidak Ada & 87 & 53,7 & 103 & 63,6 & 190 & 58,6 \\
\hline
\end{tabular}

Berdasarkan tabel 5 diatas terlihat kelompok kontrol sebanyak 59 (36,4\%), bahwa proporsi kejadian DM tipe 2 pada sedangkan tidak ada riwayat DM sebanyak yang ada riwayat DM kelompok kasus 103 (63,6\%). Penderita DM tipe 2 yang ada sebanyak 75 (46,3\%), sedangkan tidak ada riwayat DM lebih banyak pada kelompok riwayat DM sebanyak 87 (53,7\%). Kejadian kasus (75) dari pada kelompok kontrol (59). DM tipe 2 pada yang ada riwayat DM Aktivitas Fisik

Tabel 6 Distribusi Frekuensi Aktivitas Fisik Pada Kasus Dan Kontrol Di Poliklinik Penyakit Dalam RSPAD Gatot Subroto Jakarta Pusat Tahun 2017

\begin{tabular}{|c|c|c|c|c|c|c|}
\hline \multirow{2}{*}{ Aktivitas Fisik } & \multicolumn{2}{|c|}{ Kasus } & \multicolumn{2}{c|}{ Kontrol } & \multicolumn{2}{c|}{ Total } \\
\cline { 2 - 7 } & $\mathrm{n}$ & $\%$ & $\mathrm{n}$ & $\%$ & $\mathrm{n}$ & $\%$ \\
\hline Kurang & 125 & 77,2 & 66 & 40,7 & 191 & 59,0 \\
Cukup & 37 & 22,8 & 96 & 59,3 & 133 & 41,0 \\
\hline
\end{tabular}

Berdasarkan tabel 6 diatas terlihat kontrol sebanyak 66 (40,7\%), sedangkan bahwa proporsi kejadian DM tipe 2 pada cukup sebanyak 96 (59,3\%). Penderita DM aktivitas fisik kurang kelompok kasus tipe 2 dengan aktivitas fisik kurang lebih sebanyak 125 (77,2\%), sedangkan cukup banyak pada kelompok kasus (125) dari sebanyak 37 (22,8\%). Kejadian DM tipe 2 pada kelompok kontrol (66).

pada aktivitas fisik kurang kelompok Pola Makan 
Tabel 7 Distribusi Frekuensi Pola Makan Pada Kasus Dan Kontrol Di Poliklinik Penyakit Dalam RSPAD Gatot Subroto Jakarta Pusat Tahun 2017

\begin{tabular}{|c|c|c|c|c|c|c|}
\hline \multirow{2}{*}{ Pola Makan } & \multicolumn{2}{|c|}{ Kasus } & \multicolumn{2}{c|}{ Kontrol } & \multicolumn{2}{c|}{ Total } \\
\cline { 2 - 7 } & $\mathrm{n}$ & $\%$ & $\mathrm{n}$ & $\%$ & $\mathrm{n}$ & $\%$ \\
\hline Tidak Seimbang & 102 & 63,0 & 72 & 44,4 & 174 & 53,7 \\
Seimbang & 60 & 37,0 & 90 & 55,6 & 150 & 46,3 \\
\hline
\end{tabular}

Berdasarkan tabel 7 diatas terlihat kontrol sebanyak $72(44,4 \%)$, sedangkan bahwa proporsi kejadian DM tipe 2 pada seimbang sebanyak 90 (55,6\%). Penderita pola makan tidak seimbang kelompok kasus DM tipe 2 yang pola makan tidak seimbang sebanyak $102(63,0 \%)$, sedangkan seimbang lebih banyak pada kelompok kasus (102) sebanyak 60 (37,0\%). Kejadian DM tipe 2 dari pada kelompok kontrol (72). pada pola makan tidak seimbang kelompok Kebiasaan Merokok

Tabel 8 Distribusi Frekuensi Kebiasaan Merokok Pada Kasus Dan Kontrol Di Poliklinik Penyakit Dalam RSPAD Gatot Subroto Jakarta Pusat Tahun 2017

\begin{tabular}{|c|c|c|c|c|c|c|}
\hline \multirow{2}{*}{ Kebiasaan Merokok } & \multicolumn{2}{|c|}{ Kasus } & \multicolumn{2}{c|}{ Kontrol } & \multicolumn{2}{c|}{ Total } \\
\cline { 2 - 7 } & $\mathrm{n}$ & $\%$ & $\mathrm{n}$ & $\%$ & $\mathrm{n}$ & $\%$ \\
\hline Merokok & 55 & 34,0 & 46 & 28,4 & 101 & 31,2 \\
Tidak Merokok & 107 & 66,0 & 116 & 71,6 & 223 & 68,8 \\
\hline
\end{tabular}

Berdasarkan tabel 8 diatas terlihat kelompok kontrol sebanyak $46 \quad(28,4 \%)$, bahwa proporsi kejadian DM tipe 2 pada sedangkan tidak merokok sebanyak 116 responden yang merokok kelompok kasus $(71,6 \%)$. Penderita DM tipe 2 yang merokok sebanyak 55 (34,0\%), sedangkan tidak lebih banyak pada kelompok kasus (55) dari merokok sebanyak 107 (66,0\%). Kejadian pada kelompok kontrol (46).

DM tipe 2 pada responden yang merokok Obesitas

Tabel 9 Distribusi Frekuensi Obesitas Pada Kasus Dan Kontrol Di Poliklinik Penyakit Dalam RSPAD Gatot Subroto Jakarta Pusat Tahun 2017

\begin{tabular}{|c|c|c|c|c|c|c|}
\hline \multirow{2}{*}{ Obesitas } & \multicolumn{2}{|c|}{ Kasus } & \multicolumn{2}{c|}{ Kontrol } & \multicolumn{2}{c|}{ Total } \\
\cline { 2 - 7 } & $\mathrm{n}$ & $\%$ & $\mathrm{n}$ & $\%$ & $\mathrm{n}$ & $\%$ \\
\hline Kegemukan & 85 & 52,5 & 48 & 29,6 & 133 & 41,0 \\
Normal & 77 & 47,5 & 114 & 70,4 & 191 & 59,0 \\
\hline
\end{tabular}

Berdasarkan tabel 9 diatas terlihat normal sebanyak 114 (70,4\%). Penderita bahwa proporsi kejadian DM tipe 2 pada DM tipe 2 yang kegemukan lebih banyak responden yang kegemukan kelompok kasus pada kelompok kasus (85) dari pada sebanyak 85 (52,5\%), sedangkan normal kelompok kontrol (48). sebanyak 77 (47,5\%). Kejadian DM tipe 2 2. Analisis Bivariat pada responden yang kegemukan kelompok Pengaruh Umur Terhadap Kejadian DM kontrol sebanyak 48 (29,6\%), sedangkan Tipe 2

Tabel 10. Pengaruh Umur Terhadap Kejadian DM Tipe 2 Di Poliklinik Penyakit Dalam RSPAD Gatot Subroto Jakarta Pusat Tahun 2017

\begin{tabular}{|c|c|c|c|c|c|c|c|c|}
\hline \multirow{3}{*}{ Umur } & \multicolumn{6}{|c|}{ Kejadian DM Tipe 2} & \multirow{3}{*}{$\begin{array}{c}P \\
\text { value }\end{array}$} & \multirow{3}{*}{$\begin{array}{c}\text { OR } \\
(95 \% \mathrm{CI})\end{array}$} \\
\hline & \multicolumn{2}{|c|}{ Kasus } & \multicolumn{2}{|c|}{ Kontrol } & \multicolumn{2}{|c|}{ Total } & & \\
\hline & $\mathrm{n}$ & $\%$ & $n$ & $\%$ & $\mathrm{n}$ & $\%$ & & \\
\hline$\geq 40$ Tahun & 136 & 84,0 & 87 & 53,7 & 223 & 68,8 & \multirow{3}{*}{0,000} & \multirow{3}{*}{$\begin{array}{c}4,509 \\
(2,678-7,592)\end{array}$} \\
\hline$<40$ Tahun & 26 & 16,0 & 75 & 46,3 & 101 & 31,2 & & \\
\hline Jumlah & 162 & 100 & 162 & 100 & 324 & 100 & & \\
\hline
\end{tabular}

Berdasarkan tabel 10 hasil pengaruh antara kasus dan kontrol sebesar 30,3\%. umur terhadap kejadian DM tipe 2 bahwa Hasil uji Chi-Square didapatkan $p$ value = responden yang berumur $\geq 40$ tahun 0,000. Karena $0,000<0,05$ maka beda proporsinya pada kasus yaitu $84,0 \%$ dan proporsi tersebut bermakna, yang artinya kelompok kontrol $53,7 \%$. Beda proporsi ada pengaruh umur terhadap kejadian DM 
tipe 2 di poliklinik penyakit dalam RSPAD yang berumur $\geq 40$ tahun berpeluang 4,5 Gatot Subroto Jakarta Pusat Tahun 2017. kali menderita DM tipe 2 dibanding kontrol.

Hasil perhitungan OR 95\% CI = Pengaruh Jenis Kelamin Terhadap 4,509 (2,678-7,592) yang artinya responden Kejadian DM Tipe 2

Tabel 11 Pengaruh Jenis Kelamin Terhadap Kejadian DM Tipe 2 Di Poliklinik Penyakit Dalam RSPAD Gatot Subroto Jakarta Pusat Tahun 2017

\begin{tabular}{|c|c|c|c|c|c|c|c|c|}
\hline \multirow{3}{*}{ Jenis Kelamin } & \multicolumn{6}{|c|}{ Kejadian DM Tipe 2} & \multirow{3}{*}{$\begin{array}{c}P \\
\text { value }\end{array}$} & \multirow{3}{*}{$\begin{array}{c}\text { OR } \\
(95 \% \mathrm{CI})\end{array}$} \\
\hline & \multicolumn{2}{|c|}{ Kasus } & \multicolumn{2}{|c|}{ Kontrol } & \multicolumn{2}{|c|}{ Total } & & \\
\hline & $\mathrm{n}$ & $\%$ & $\mathrm{n}$ & $\%$ & $\mathrm{n}$ & $\%$ & & \\
\hline Perempuan & 92 & 56,8 & 68 & 42,0 & 160 & 49,4 & & \\
\hline Laki-Laki & 70 & 43,2 & 94 & 58,0 & 164 & 50,6 & 0,011 & $\begin{array}{c}1,811 \\
(170-2822\end{array}$ \\
\hline Jumlah & 162 & 100 & 162 & 100 & 324 & 100 & & \\
\hline
\end{tabular}

Berdasarkan tabel 11 hasil pengaruh kejadian DM tipe 2 di poliklinik penyakit jenis kelamin terhadap kejadian DM tipe 2 dalam RSPAD Gatot Subroto Jakarta Pusat bahwa responden yang berjenis kelamin Tahun 2017.

perempuan proporsinya pada kasus yaitu Hasil perhitungan OR 95\% CI = $56,8 \%$ dan kelompok kontrol 42,0\%. Beda 1,817 $(1,170-2,822)$ yang artinya responden proporsi antara kasus dan kontrol sebesar yang berjenis kelamin perempuan 14,8\%. Hasil uji Chi-Square didapatkan $p$ berpeluang 1,8 kali menderita DM tipe 2 value $=0,011$. Karena $0,011<0,05$ maka dibanding kontrol.

beda proporsi tersebut bermakna, yang Pengaruh Pendidikan Terhadap artinya ada pengaruh jenis kelamin terhadap Kejadian DM Tipe 2

Tabel 12 Pengaruh Pendidikan Terhadap Kejadian DM Tipe 2 Di Poliklinik Penyakit Dalam RSPAD Gatot Subroto Jakarta Pusat Tahun 2017

\begin{tabular}{|c|c|c|c|c|c|c|c|c|}
\hline \multirow{3}{*}{ Pendidikan } & \multicolumn{6}{|c|}{ Kejadian DM Tipe 2} & \multirow{3}{*}{$\begin{array}{c}P \\
\text { value }\end{array}$} & \multirow{3}{*}{$\begin{array}{c}\text { OR } \\
(95 \% \mathrm{CI})\end{array}$} \\
\hline & \multicolumn{2}{|c|}{ Kasus } & \multicolumn{2}{|c|}{ Kontrol } & \multicolumn{2}{|c|}{ Total } & & \\
\hline & $\mathrm{n}$ & $\%$ & $\mathrm{n}$ & $\%$ & $\mathrm{n}$ & $\%$ & & \\
\hline Rendah & 40 & 24,7 & 33 & 20,4 & 76 & 23,5 & \multirow{3}{*}{0,425} & \multirow{3}{*}{$\begin{array}{c}1,282 \\
(0,760-2,163)\end{array}$} \\
\hline Tinggi & 122 & 75,3 & 129 & 79,6 & 248 & 76,5 & & \\
\hline Jumlah & 162 & 100 & 162 & 100 & 324 & 100 & & \\
\hline
\end{tabular}

Berdasarkan tabel 12 hasil pengaruh tersebut tidak bermakna, yang artinya tidak pendidikan terhadap kejadian DM tipe 2 ada Pengaruh pendidikan terhadap kejadian bahwa responden yang berpendidikan DM tipe 2 di poliklinik penyakit dalam rendah proporsinya pada kasus yaitu 24,7\% RSPAD Gatot Subroto Jakarta Pusat Tahun dan kelompok kontrol 20,4\%. Beda proporsi 2017.

antara kasus dan kontrol sebesar 4,3\%. Hasil Pengaruh Riwayat DM Terhadap uji Chi-Square didapatkan $p$ value $=0,425$. Kejadian DM Tipe 2

Karena $0,425>0,05$ maka beda proporsi

Tabel 13 Pengaruh Riwayat DM Terhadap Kejadian DM Tipe 2 Di Poliklinik Penyakit Dalam RSPAD Gatot Subroto Jakarta Pusat Tahun 2017

\begin{tabular}{|c|c|c|c|c|c|c|c|c|}
\hline \multirow{3}{*}{ Riwayat DM } & \multicolumn{6}{|c|}{ Kejadian DM Tipe 2} & \multirow{3}{*}{$\begin{array}{c}P \\
\text { value }\end{array}$} & \multirow{3}{*}{$\begin{array}{c}\text { OR } \\
(95 \% \mathrm{CI})\end{array}$} \\
\hline & \multicolumn{2}{|c|}{ Kasus } & \multicolumn{2}{|c|}{ Kontrol } & \multicolumn{2}{|c|}{ Total } & & \\
\hline & $\mathrm{n}$ & $\%$ & $\mathrm{n}$ & $\%$ & $\mathrm{n}$ & $\%$ & & \\
\hline Ada & 75 & 46,3 & 59 & 36,4 & 134 & 41,4 & & \\
\hline Tidak Ada & 87 & 53,7 & 103 & 63,6 & 190 & 58,6 & 0,091 & \\
\hline Jumlah & 162 & 100 & 162 & 100 & 324 & 100 & & \\
\hline
\end{tabular}

Berdasarkan tabel 13 hasil pengaruh kelompok kontrol 36,4\%. Beda proporsi riwayat DM terhadap kejadian DM tipe 2 antara kasus dan kontrol sebesar 9,9\%. Hasil bahwa responden yang ada riwayat DM uji Chi-Square didapatkan $p$ value $=0,091$. proporsinya pada kasus yaitu 46,3\% dan Karena 0,091>0,05 maka beda proporsi 
tersebut tidak bermakna, yang artinya tidak RSPAD Gatot Subroto Jakarta Pusat Tahun ada pengaruh riwayat DM terhadap kejadian 2017.

DM tipe 2 di poliklinik penyakit dalam Pengaruh Aktivitas Fisik Terhadap Kejadian DM Tipe 2

Tabel 14 Pengaruh Aktivitas Fisik Terhadap Kejadian DM Tipe 2 Di Poliklinik Penyakit Dalam RSPAD Gatot Subroto Jakarta Pusat Tahun 2017

\begin{tabular}{|c|c|c|c|c|c|c|c|c|}
\hline \multirow{3}{*}{$\begin{array}{l}\text { Aktivitas } \\
\text { Fisik }\end{array}$} & \multicolumn{6}{|c|}{ Kejadian DM Tipe 2} & \multirow{3}{*}{$\begin{array}{c}P \\
\text { value }\end{array}$} & \multirow{3}{*}{$\begin{array}{c}\text { OR } \\
(95 \% \mathrm{CI})\end{array}$} \\
\hline & \multicolumn{2}{|c|}{ Kasus } & \multicolumn{2}{|c|}{ Kontrol } & \multicolumn{2}{|c|}{ Total } & & \\
\hline & $\mathrm{n}$ & $\%$ & $n$ & $\%$ & $\mathrm{n}$ & $\%$ & & \\
\hline Kurang & 125 & 77,2 & 66 & 40,7 & 191 & 59,0 & \multirow{3}{*}{0,000} & \multirow{3}{*}{$\begin{array}{c}4,914 \\
(3,033-7,961)\end{array}$} \\
\hline Cukup & 37 & 22,8 & 96 & 59,3 & 133 & 41,0 & & \\
\hline Jumlah & 162 & 100 & 162 & 100 & 324 & 100 & & \\
\hline
\end{tabular}

Berdasarkan tabel 14 hasil pengaruh kejadian DM tipe 2 di poliklinik penyakit aktivitas fisik terhadap kejadian DM tipe 2 dalam RSPAD Gatot Subroto Jakarta Pusat bahwa responden yang aktivitas fisik kurang Tahun 2017. Hasil perhitungan OR 95\% CI proporsinya pada kasus yaitu $77,2 \%$ dan $=4,914 \quad(3,033-7,961)$ yang artinya kelompok kontrol 40,7\%. Beda proporsi responden yang aktivitas fisik kurang antara kasus dan kontrol sebesar 36,5\%. berpeluang 4,9 kali menderita DM tipe 2 Hasil uji Chi-Square didapatkan $p$ value $=$ dibanding kontrol.

0,000. Karena $0,000<0,05$ maka beda Pengaruh Pola Makan Terhadap proporsi tersebut bermakna, yang artinya Kejadian DM Tipe 2

ada pengaruh aktivitas fisik terhadap

Tabel 15 Pengaruh Pola Makan Terhadap Kejadian DM Tipe 2 Di Poliklinik Penyakit Dalam RSPAD Gatot Subroto Jakarta Pusat Tahun 2017

\begin{tabular}{|c|c|c|c|c|c|c|c|c|}
\hline \multirow{3}{*}{ Pola Makan } & \multicolumn{6}{|c|}{ Kejadian DM Tipe 2} & \multirow{3}{*}{$\begin{array}{c}P \\
\text { value }\end{array}$} & \multirow{3}{*}{$\begin{array}{c}\text { OR } \\
(95 \% \mathrm{CI})\end{array}$} \\
\hline & \multicolumn{2}{|c|}{ Kasus } & \multicolumn{2}{|c|}{ Kontrol } & \multicolumn{2}{|c|}{ Total } & & \\
\hline & $\mathrm{n}$ & $\%$ & $\mathrm{n}$ & $\%$ & $\mathrm{n}$ & $\%$ & & \\
\hline Tidak Seimbang & 102 & 63,0 & 72 & 44,4 & 174 & 53,7 & \multirow{3}{*}{0,001} & \multirow{3}{*}{$\begin{array}{c}2,125 \\
(1,362-3,315)\end{array}$} \\
\hline Seimbang & 60 & 37,0 & 90 & 55,6 & 150 & 46,3 & & \\
\hline Jumlah & 162 & 100 & 162 & 100 & 324 & 100 & & \\
\hline
\end{tabular}

Berdasarkan tabel 15 hasil pengaruh kejadian DM tipe 2 di poliklinik penyakit pola makan terhadap kejadian DM tipe 2 dalam RSPAD Gatot Subroto Jakarta Pusat bahwa responden yang pola makan tidak Tahun 2017. Hasil perhitungan OR 95\% CI seimbang proporsinya pada kasus yaitu $=2,125 \quad(1,362-3,315)$ yang artinya $63,0 \%$ dan kelompok kontrol 44,4\%. Beda responden yang pola makan tidak seimbang proporsi antara kasus dan kontrol sebesar berpeluang 2,1 kali menderita DM tipe 2 18,6\%. Hasil uji Chi-Square didapatkan $p$ dibanding kontrol.

value $=0,001$. Karena $0,001<0,05$ maka Pengaruh Kebiasaan Merokok Terhadap beda proporsi tersebut bermakna, yang Kejadian DM Tipe 2

artinya ada pengaruh pola makan terhadap

Tabel 16 Pengaruh Kebiasaan Merokok Terhadap Kejadian DM Tipe 2 Di Poliklinik

Penyakit Dalam RSPAD Gatot Subroto Jakarta Pusat Tahun 2017

\begin{tabular}{|c|c|c|c|c|c|c|c|c|}
\hline \multirow{3}{*}{$\begin{array}{c}\text { Kebiasaan } \\
\text { Merokok }\end{array}$} & \multicolumn{6}{|c|}{ Kejadian DM Tipe 2} & \multirow{3}{*}{$\begin{array}{c}P \\
\text { value }\end{array}$} & \multirow{3}{*}{$\begin{array}{c}\text { OR } \\
(95 \% \mathrm{CI})\end{array}$} \\
\hline & \multicolumn{2}{|c|}{ Kasus } & \multicolumn{2}{|c|}{ Kontrol } & \multicolumn{2}{|c|}{ Total } & & \\
\hline & $\mathrm{n}$ & $\%$ & $\mathrm{n}$ & $\%$ & $\mathrm{n}$ & $\%$ & & \\
\hline Merokok & 55 & 34,0 & 46 & 28,4 & 101 & 31,2 & \multirow{3}{*}{0,337} & \multirow{3}{*}{$\begin{array}{c}1,296 \\
(0,809-2,077)\end{array}$} \\
\hline Tidak Merokok & 107 & 66,0 & 116 & 71,6 & 223 & 68,8 & & \\
\hline Jumlah & 162 & 100 & 162 & 100 & 324 & 100 & & \\
\hline
\end{tabular}

Berdasarkan tabel 6 hasil pengaruh tipe 2 bahwa responden yang merokok kebiasaan merokok terhadap kejadian DM proporsinya pada kasus yaitu 34,0\% dan 
kelompok kontrol 28,4\%. Beda proporsi DM tipe 2 di poliklinik penyakit dalam antara kasus dan kontrol sebesar 5,6\%. Hasil RSPAD Gatot Subroto Jakarta Pusat Tahun uji Chi-Square didapatkan $p$ value $=0,337.2017$.

Karena 0,337>0,05 maka beda proporsi Pengaruh Obesitas Terhadap Kejadian tersebut tidak bermakna, yang artinya tidak DM Tipe 2

ada pengaruh kebiasaan terhadap kejadian

Tabel 17 Pengaruh Obesitas Terhadap Kejadian DM Tipe 2 Di Poliklinik Penyakit Dalam RSPAD Gatot Subroto Jakarta Pusat Tahun 2017

\begin{tabular}{|c|c|c|c|c|c|c|c|c|}
\hline \multirow{3}{*}{ Obesitas } & \multicolumn{6}{|c|}{ Kejadian DM Tipe 2} & \multirow{3}{*}{$\begin{array}{c}P \\
\text { value }\end{array}$} & \multirow{3}{*}{$\begin{array}{c}\text { OR } \\
(95 \% \mathrm{CI})\end{array}$} \\
\hline & \multicolumn{2}{|c|}{ Kasus } & \multicolumn{2}{|c|}{ Kontrol } & \multicolumn{2}{|c|}{ Total } & & \\
\hline & $\mathrm{n}$ & $\%$ & $\mathrm{n}$ & $\%$ & $\mathrm{n}$ & $\%$ & & \\
\hline Kegemukan & 85 & 52,5 & 48 & 29,6 & 133 & 41,0 & \multirow{3}{*}{0,000} & \multirow{3}{*}{$\begin{array}{c}2,622 \\
(1,660-4,140)\end{array}$} \\
\hline Normal & 77 & 47,5 & 114 & 70,4 & 191 & 59,0 & & \\
\hline Jumlah & 162 & 100 & 162 & 100 & 324 & 100 & & \\
\hline
\end{tabular}

Berdasarkan tabel 17 hasil pengaruh maka akan semakin besar kemungkinan obesitas terhadap kejadian DM tipe 2 bahwa menderita DM tipe 2 karena kondisi responden yang kegemukan proporsinya kesehatan yang mulai menurun dan sistem pada kasus yaitu $52,5 \%$ dan kelompok kekebalan tubuh juga menurun maka akan kontrol 29,6\%. Beda proporsi antara kasus lebih mudah terkenah DM tipe 2. dan kontrol sebesar 22,9\%. Hasil uji Chi- Responden kasus DM tipe 2 pada penelitian Square didapatkan $p$ value $=0,000$. Karena ini lebih banyak berusia $\geq 40$ tahun, hal ini $0,000<0,05$ maka beda proporsi tersebut menunjukan bahwa usia memang bermakna, yang artinya ada pengaruh mengpengaruhi kejadian DM tipe 2 .

obesitas terhadap kejadian DM tipe 2 di Umur Risiko untuk Menderita poliklinik penyakit dalam RSPAD Gatot Intoleransi Glukosa Meningkat Seiring Subroto Jakarta Pusat Tahun 2017. Hasil Pertambahan Usia. Usia > 40 Tahun Harus perhitungan OR 95\% CI = 2,622 (1,660- Dilakukan Pemeriksaan DM. Prevalensi 4,140 ) yang artinya responden yang responden yang mempunyai riwayat DM kegemukan berpeluang 2,6 kali menderita cenderung meningkat dengan bertambahnya DM tipe 2 dibanding kontrol.

\section{Pembahasan}

Pengaruh Umur Terhadap Kejadian DM tipe 2

Berdasarkan hasil pengaruh umur terhadap kejadian DM tipe 2 bahwa 2 responden yang berumur $\geq 40$ tahun Jakarta Barat Tahun 2012. Dari hasil proporsinya pada kasus yaitu $84,0 \%$ dan penelitiannya menunjukan ada hubungan kelompok kontrol 53,7\%. Beda proporsi yang bermakna antara umur dengan antara kasus dan kontrol sebesar 30,3\%. kejadian DM tipe 2.

Hasil uji Chi-Square didapatkan $p$ value $=$ 0,000. Karena 0,000 < 0,05 maka beda dilakukan Radio Putro ( 2011), dari hasil proporsi tersebut bermakna, yang artinya penelitiannya didapatkan nilai $\mathrm{OR}=9,3$, ada pengaruh umur terhadap kejadian DM yang artinya orang yang berumur $\geq 40$ tahun tipe 2. Hasil perhitungan OR 95\% CI = lebih berisiko 9,3 kali lebih besar menderita 4,509 (2,678-7,592) yang artinya responden DM tipe 2 dibandingkan dengan orang yang yang berumur $\geq 40$ tahun berpeluang 4,5 berumur $<40$ tahun.

kali menderita DM tipe 2 dibanding kontrol.

Dari hasil penelitian diketahui dilakukan Niciane Bandeira ( 2013), dari bahwa umur berpengaruh terhadap kejadian hasil penelitiannya didapatkan nilai $\mathrm{OR}=$ DM tipe 2. Semakin tinggi usia seseorang 3,0, yang artinya orang yang berumur $\geq 40$ 
tahun lebih berisiko 3 kali lebih besar berjudul" Faktor Risiko Kejadian DM type menderita DM tipe 2 dibandingkan dengan 2 di Puskesmas Kecamatan Cengkareng orang yang berumur $<40$ tahun.

Jakarta Barat Tahun 2012. Dari hasil

Sejalan juga dengan penelitian yang penelitiannya menunjukan ada hubungan dilakukan Sri Trisnawati ( 2013), dari hasil yang bermakna antara umur dengan penelitiannya didapatkan nilai $\mathrm{OR}=4,0$, kejadian DM tipe 2 .

yang artinya orang yang berumur $\geq 40$ tahun Hasil penelitian ini bertentangan lebih berisiko 4 kali lebih besar menderita dengan penelitian Zuheri (2014), dari hasil DM tipe 2 dibandingkan dengan orang yang penelitiannya didapatkan nilai $P$ value berumur $<40$ tahun. sebesar 0,612 yang artinya tidak ada

Kesimpulan untuk pengaruh umur hubungan antara jenis kelamin dengan terhadap DM tipe 2 dari hasil penelitian ini kejadian DM tipe 2.

dan didukung oleh penelitian lainnya yang

Kesimpulan untuk pengaruh jenis bahwa umur mempengaruhi kejadian DM kelamin terhadap kejadian DM tipe 2 dari tipe 2.

hasil penelitian ini dan didukung oleh

Pengaruh Jenis Kelamin Terhadap penelitian lainnya yang bahwa jenis kelamin Kejadian DM tipe 2 mempengaruhi kejadian DM tipe 2.

Berdasarkan hasil pengaruh jenis kelamin terhadap kejadian DM tipe 2 bahwa responden yang berjenis kelamin perempuan proporsinya pada kasus yaitu 56,8\% dan kelompok kontrol 42,0\%. Beda proporsi antara kasus dan kontrol sebesar 14,8\%. Hasil uji Chi-Square didapatkan $p$ value $=$ 0,011 . Karena $0,011<0,05$ maka beda Pengaruh Pendidikan Terhadap Kejadian DM tipe 2

Berdasarkan hasil pengaruh pendidikan terhadap kejadian DM tipe 2 bahwa responden yang berpendidikan rendah proporsinya pada kasus yaitu $24,7 \%$ dan kelompok kontrol 20,4\%. Beda proporsi antara kasus dan kontrol sebesar 4,3\%. Hasil proporsi tersebut bermakna, yang artinya uji Chi-Square didapatkan $p$ value $=0,425$. ada pengaruh jenis kelamin terhadap Karena 0,425>0,05 maka beda proporsi kejadian DM tipe 2. tersebut tidak bermakna, yang artinya tidak

Hasil perhitungan OR $95 \% \mathrm{CI}=$ ada pengaruh pendidikan terhadap kejadian $1,817(1,170-2,822)$ yang artinya responden DM tipe 2.

yang berjenis kelamin perempuan berpeluang 1,8 kali menderita DM tipe 2 dibanding kontrol.

Sebagian besar responden kasus DM tipe 2 adalah berjenis kelamin perempuan, hal ini menunjukan bahwa perempuang memang lebih rentan terhadap penyakit DM tipe 2 karna biasanya IMT wanita lebih mudah meningkat dibandingkan laki-laki.

Wanita lebih berisiko mengidap diabetes karena secara fisik wanita memiliki peluang peningkatan indeks masa tubuh yang lebih besar. Sindroma siklus bulanan (premenstrual syndrome), pasca-menopouse yang membuat distribusi lemak tubuh menjadi mudah terakumulasi akibat proses hormonal tersebut sehingga wanita berisiko menderita diabetes mellitus tipe 2 (Shara Kurnia \& Soedijono, 2013)

Hasil penelitian ini sejalan dengan penelitian Shara Kurnia (2013) yang
Sebagian besar responden kasus maupun kontrol memiliki berpendidikan tinggi atau $\geq$ SMA. Pendidikan memang erat hubungannya dengan pengetahuan, secara teoritis jika seseorang berpendidikan tinggi maka pengetahuannya tentang kesehatan akan lebih baik, dengan informasi yang didapat maka seseorang akan lebih mengerti menghindari penyakit DM tipe.

Akan tetapi hal tersebut tidaklah mutlak, karna meskipun seseorang berpendidikan tinggi dan memiliki pengetahuan yang baik tentang DM tipe 2 belum tentu seseorang akan terhindar dari penyakit DM, karna pendidikan bukanlah satu-satunya faktor yang mempengaruhi penyakit DM.

Pendidikan menjadi modal yang baik bagi seseorang untuk meningkatkan pola pikir dan perilaku sehat, karena itu pendidikan dapat membantu seseorang untuk memahami penyakit dan gejala- 
gejalanya (Noman, 2004). Berbagai studi menunjukkan terdapat hubungan yang bermakna antara tingkat pendidikan dengan kejadian DM tipe 2.

Status pendidikan yang rendah dapat mempengaruhi kesadaran yang lebih rendah, peluang yang lebih rendah untuk pencegahan suatu penyakit, dan di sisi lain status pendidikan yang lebih tinggi dapat mempengaruhi melalui faktor gaya hidup. Oleh karena itu pendidikan mungkin tidak memiliki hubungan langsung dengan perkembangan diabetes (Sumanth $\mathrm{M}$ et al, 2012)

Hasil ini bertentangan dengan penelitian yang dilakukan Shara dan Setyorogo di Puskesmas Cengkareng (2012), menunjukkan tidak ada hubungan antara pendidikan dengan kejadian Diabetes Melitus tipe 2. Sementara penelitian yang dilakukan Nainggolan dkk (2013), menunjukkan pendidikan rendah dan menengah lebih bersifat protektif dibandingkan dengan latar belakang pendidikan tinggi. Pendidikan tinggi memiliki risiko 1,43 kali lebih tinggi dibanding pendidikan rendah.

Dan bertentangan juga dengan penelitian Zahtamal dkk (2007), yang menyatakan bahwa pendidikan secara tidak langsung berhubungan dengan pengetahuan pasien. Hasil studi menunjukkan terdapat hubungan antara pengetahuan dengan kejadian DM dan sebagai faktor protektif terhadap DM.

Kesimpulan untuk pengaruh pendidikan terhadap kejadian DM tipe 2 dari hasil penelitian ini menunjukan tidak ada pengaruh pendidikan terhadap kejadian DM tipe 2, berbeda dengan hasil penelitian yang dilakukan oleh peneltiti sebelumnya, hal ini disebabkan kemungkinan terjadi bias seleksi saat pemilihan sampel, karna dalam penelitian teknik sampling yang digunakan adalah adalah purposive sampling.

\section{Pengaruh Riwayat DM Terhadap Kejadian DM tipe 2}

Berdasarkan hasil pengaruh riwayat kelompok kontrol 36,4\%. Beda proporsi antara kasus dan kontrol sebesar 9,9\%. Hasil uji Chi-Square didapatkan $p$ value $=0,091$. Karena 0,091 > 0,05 maka beda proporsi tersebut tidak bermakna, yang artinya tidak ada pengaruh riwayat DM terhadap kejadian DM tipe 2.

Riwayat DM tidak berpengaruh terhadap kejadian DM, hal ini cukup jelas terlihat bahwa responden kasus sebagian besar memang tidak memiliki riwayat DM. Meskipun seseorang yang tidak memiliki riwayat penyakit DM dalam keluarga, tetapi pola hidupnya tidak sehat, maka seseorang akan dengan mudah terserang penyakit tidak menular seperti DM tipe 2.

Secara teoritis faktor keturunan banyak dijumpai pada penderita diabetes tipe 1. Namun faktor keturunan bukan satusatunya penyebab, akan tetapi lebih karena adanya keterkaitan antara faktor keturunan dengan dan faktor lingkungan. Artinya, bahwa seseorang yang menderita DM tipe 1 pada dasarnya sudah mempunyai potensi secara keturunan menderita DM. Seseorang yang mempunyai keluarga yang menderita DM, akan mempunyai risiko sekitar $6 \%$ jika dibandingkan dengan keluarga yang tidak memiki keturunan diabetes mellitus (Waris, 2015).

Hasil ini bertentangan dengan penelitian yang dilakukan Liu Liya, et al, (2013) di Cina. Dari hasil penelitiannya diperoleh nilai $\mathrm{OR}=11,2$ yang artinya orang yang memiliki riwayat penyakit DM dalam keluarga memiliki risiko 11 kali lebih besar menderita DM tipe 2 dibandingkan dengan orang yang tidak memiliki riwayat DM dalam keluarga.

Bertentangan juga dengan penelitian yang dilakukan Kaban (2007). Hasil uji chi square diperoleh nilai OR sebesar 11,3 yang artinya orang yang memiliki riwayat penyakit DM dalam keluarga memiliki risiko 11 kali lebih besar menderita DM tipe 2 dibandingkan dengan orang yang tidak memiliki riwayat DM dalam keluarga.

Bertentangan juga dengan penelitian DM terhadap kejadian DM tipe 2 bahwa yang dilakukan Zuheri (2014). Hasil uji chi responden yang ada riwayat DM square diperoleh nilai OR sebesar 9,5 yang proporsinya pada kasus yaitu $46,3 \%$ dan artinya orang yang memiliki riwayat 
penyakit DM dalam keluarga memiliki risiko 9 kali lebih besar menderita DM tipe 2 dibandingkan dengan orang yang tidak memiliki riwayat DM dalam keluarga.

Bertentangan juga dengan penelitian yang dilakukan Wahyu Ratri (2016). Hasil uji chi square diperoleh nilai $p$ value sebesar 0,006 yang artinya ada hubungan antara riwayat DM dengan kejaidan DM tipe 2, dan OR sebesar 3,2 yang artinya orang yang memiliki riwayat penyakit DM dalam keluarga memiliki risiko 3 kali lebih besar menderita DM tipe 2 dibandingkan dengan orang yang tidak memiliki riwayat DM dalam keluarga.

Kesimpulan untuk pengaruh riwayat DM terhadap kejadian DM tipe 2 dari hasil penelitian ini menunjukan tidak ada pengaruh riwayat DM terhadap kejadian DM tipe 2, berbeda dengan hasil penelitian yang dilakukan oleh peneltiti sebelumnya, hal ini disebabkan karna sampel dalam penelitian ini cukup kecil dibandingkan dengan sampel peneliti sebelumnya.

\section{Pengaruh Aktivitas Fisik Terhadap Kejadian DM tipe 2}

Berdasarkan hasil pengaruh aktivitas fisik terhadap kejadian DM tipe 2 bahwa responden yang aktivitas fisik kurang proporsinya pada kasus yaitu $77,2 \%$ dan kelompok kontrol 40,7\%. Beda proporsi antara kasus dan kontrol sebesar 36,5\%. Hasil uji Chi-Square didapatkan $p$ value $=$ 0,000. Karena $0,000<0,05$ maka beda proporsi tersebut bermakna, yang artinya ada pengaruh aktivitas fisik terhadap kejadian DM tipe 2.

Hasil perhitungan OR $95 \% \mathrm{CI}=$ 4,914 (3,033-7,961) yang artinya responden yang aktivitas fisik kurang berpeluang 4,9 kali menderita DM tipe 2 dibanding kontrol.

Dari hasil penelitian jenis aktivitas fisik yang paling banyak dilakukan oleh responden kelompok kasus adalah mengerjakan pekerjaan rumah yaitu sebanyak 46\%. Hanya ada beberapa responden saja yang melakukan aktivitas fisik seperti jogging dan bersepeda.

Aktivitas fisik memang sangat erat hubungan dengan penyakit tidak menular, dengan kejadian dm Tipe 2 dan $\mathrm{OR}=7,7$ karna apabila seseorang tidak melakukan yang artinya orang dengan aktivitas fisik aktivitas fisik 30 menit perhari atau 3 kali dalam seminggu, maka akan terjadi penumpukan lemak dalam tubuh dan insulin tidak mencukupi untuk mengubah glukosa menjadi energi maka akan timbul DM maka glukosa akan meningkat dan akan terjadi DM tipe 2. Sebagian besar responden mengakui kalau mereka memang kurang melakukan aktivitas fisik sehari-hari, karna kesibukan pekerjaan yang hanya duduk dikantor dan hanya menggerakan otot tangan.

Kurang melakukan aktivitas fisik atau dalam bahasa sederhananya "malas bergerak" sangat perlu untuk mencegah terjadinya DM. Dalam sebuah penelitian yang dilakukan oleh Knowler, dkk (2002), mengatakan delapan dari 10 penderita DM yang terjadi pada usia lanjut disebabkan empat faktor kebiasaan sehari-hari, salah satunya adalah kurang melakukan aktivitas fisik.

darah. Glukosa akan diubah menjadi energi pada saat berkatifitas fisik. Aktifitas fisik mengakibatkan insulin semakin meningkat sehingga kadar gula dalam darah akan berkurang. Pada orang yang jarang ber-olah raga, zat makanan yang masuk kedalam tubuh tidak dibakar tetapi ditimbun dalam tubuh sebagai lemak dan gula. Jika insulin tidak mencukupi untuk mengubah glukosa menjadi energi maka akan timbul DM (Betteng, 2014).

Hasil penelitian ini sejalan dengan penelitian Deby Marlina (2015). Hasil analisis uji chi square menunjukan bahwa $p$ value $=0,003$, yang artinya ada hubungan antgara aktivitas fisik dengan kejadian dm Tipe 2 dan $\mathrm{OR}=2,4$ yang artinya orang dengan aktivitas fisik kurang memiliki risiko 2,4 kali lebih besar menderita DM tipe 2 dibandingkan dengan orang dengan aktivitas fisik cukup.

Sejalan juga dengan hasil penelitan Penelitian Wahyu Ratri (2016). Analisa menggunakan uji chi-square diperoleh hasil variabel paritas dengan $p$-value $=0,000$ yang artinya ada hubungan antgara aktivitas fisik 
kurang memiliki risiko 7,7 kali lebih besar menderita DM tipe 2 dibandingkan dengan orang dengan aktivitas fisik cukup.

Sejalan juga dengan hasil penelitan Penelitian Zuheri (2014). Analisa menggunakan uji chi-square diperoleh hasil variabel paritas dengan $p$-value $=0,007$ yang artinya ada hubungan antgara aktivitas fisik dengan kejadian dm Tipe 2 dan $\mathrm{OR}=3,8$ yang artinya orang dengan aktivitas fisik kurang memiliki risiko 3,8 kali lebih besar menderita DM tipe 2 dibandingkan dengan orang dengan aktivitas fisik cukup.

Sejalan juga dengan hasil penelitan Penelitian Munawar (2014). Analisa menggunakan uji chi-square diperoleh hasil variabel paritas dengan $p$-value $=0,019$ yang artinya ada hubungan antgara aktivitas fisik dengan kejadian Diabetes Melitus dan OR= 2,3 yang artinya orang dengan aktivitas fisik kurang memiliki risiko 2,3 kali lebih besar menderita DM dibandingkan dengan orang dengan aktivitas fisik cukup.

Kesimpulan untuk

pengaruh aktivitas fisik terhadap kejadian DM tipe 2 dari hasil penelitian ini dan didukung oleh penelitian lainnya yang bahwa akivitas fisik mempengaruhi kejadian DM tipe 2.

\section{Pengaruh Pola Makan Terhadap Kejadian DM tipe 2}

Berdasarkan hasil pengaruh pola makan terhadap kejadian DM tipe 2 bahwa responden yang pola makan tidak seimbang proporsinya pada kasus yaitu $63,0 \%$ dan kelompok kontrol 44,4\%. Beda proporsi antara kasus dan kontrol sebesar 18,6\%. Hasil uji Chi-Square didapatkan $p$ value $=$ 0,001 . Karena $0,001<0,05$ maka beda proporsi tersebut bermakna, yang artinya ada pengaruh pola makan terhadap kejadian DM tipe 2.

Hasil perhitungan $\mathrm{OR} 95 \% \mathrm{CI}=$ $2,125(1,362-3,315)$ yang artinya responden yang pola makan tidak seimbang berpeluang 2,1 kali menderita DM tipe 2 dibanding kontrol.

Dari hasil penelitian pola makan yang tidak seimbang pada kelompok kasus adalah lebih banyak ke golongan kurang mengkonsumsi buah dan sayur setiap hari atau konsumsi sayur kurang dari 4 porsi sehari dan buah kurang dari 5 porsi sehari dan juga lebih banyak mengkonsumsi makanan pokok atau sumber karbohidrat lebih dari 5 porsi sehari.

Sebagian besar responden memang memiliki pola makan yang tidak seimbang atau lebih dari porsi seimbang. Hasil wawancara yang peneliti lakukan pada kelompok kasus sebagian besar responden memang mengkonsumsi sumber karboridrat dan protein yang berlebihan sedangkan kurang makan bua dan sayuran. Hal ini yang menyebabkan meningkatnya kadar gula dara dalam tubuh. Peneliti berasumsi kalau pola makan memang erat hubungannya dengan kejadian DM tipe 2, apabila seseorang mengaja pola makan dengan baik seperti konsumsi rendah gula dan tinggi serat (lebih banyak makan buah dan sayuran) maka dapat memperkecil risiko menderita DM tipe 2. Kemenkes RI (2011) menyebutkan konsumsi makanan yang tidak seimbang, tinggi gula dan rendah serat juga merupakan faktor risiko DM.

Pola makan merupakan suatu cara atau usaha dalam pengaturan jumlah dan jenis makanan dengan maksud tertentu seperti mempertahankan kesehatan, status nutrisi, mencegah atau membantu kesembuhan penyakit. Pola makan seharihari merupakan pola makan seseorang yang berhubungan dengan kebiasaan makan setiap harinya. Pola makan atau pola konsumsi merupakan susunan jenis dan jumlah makanan yang dikonsumsi seseorang atau kelompok orang pada waktu tertentu (Sudaryanto, dkk, 2014).

Makanan akan menaikkan glukosa darah, satu sampai dua jam setelah makan, glukosa darah mencapai angka paling tinggi. Manajemen perencanaan makan yang meliputi jumlah, jenis dan jadwal, diharapkan dapat mempertahankan kadar glukosa darah dan lipid dalam batas normal dan penderita mendapatkan nutrisi yang optimal (Nurlaili \& Muhamad, 2013)

Hasil penelitian ini sejalan dengan penelitian Sudaryanto A, dkk (2014). Hasil penelitiannya menunjukan ada hubungan antara pola makan dengan kejadian dm Tipe 2 dengan $\mathrm{OR}=10,0$ yang artinya seseorang 
dengan pola makan tidak seimbang ada pengaruh kebiasaan merokok terhadap memiliki risiko 10 kali lebih besar kejadian DM tipe 2.

menderita DM tipe 2 dibandingkan dengan

Hasil penelitian ini memang tidak orang dengan pola makan seimbang.

menunjukan ada ada pengaruh kebiasaan

Sejalan juga dengan hasil penelitan merokok terhadap kejadian DM, karna Penelitian Niciane Bandeira (2012) di sebagian besar kelompok kasus tidak Brazil. Hasil penelitiannya juga menunjukan merokok. hal ini bertentangan dengan teori ada hubungan antgara aktivitas fisik dengan yang menyebutkan Nikotin yang terdapat kejadian $\mathrm{dm}$ Tipe 2. Diperoleh nilai $\mathrm{OR}=$ pada asap rokok memiliki pengaruh 2,21 yang artinya seseorang dengan pola terhadap terjadinya DM tipe 2. Pengaruh makan tidak seimbang memiliki risiko 2,2 nikotin terhadap insulin di antaranya kali lebih besar menderita DM tipe 2 menyebabkan penurunan pelepasan insulin dibandingkan dengan orang dengan pola akibat aktivasi hormon katekolamin, makan seimbang.

Sejalan juga dengan hasil penelitan pengaruh negatif pada kerja insulin, Penelitian Zuheri (2014). gangguan pada sel $\beta$ pankreas dan Hasil perkembangan ke arah resistensi insulin. penelitiannya juga menunjukan ada Mekanisme- mekanisme potensial lain hubungan antgara aktivitas fisik dengan akibat paparan rokok seperti paparan rokok kejadian dm Tipe $2(\mathrm{p}=0,0001)$. Diperoleh pada ibu hamil dan menyusui juga memiliki nilai $\mathrm{OR}=9,2$ yang artinya seseorang peran terjadinya perkembangan resistensi dengan pola makan tidak seimbang insulin (Ario, 2014).

memiliki risiko 9 kali lebih besar menderita

DM tipe 2 dibandingkan dengan orang dengan pola makan seimbang.

Sejalan juga dengan hasil penelitan

Bahaya dari rokok ini memang tidak diragukan lagi bagi kesehatan seseorang. Banyak hasil penelitian yang memberikan Penelitian Kaban (2007)

Hasil menyebabkan kerusakan paru-paru, dimulai penelitiannya juga menunjukan ada hanya sedekar infeksi, merokok juga hubungan antgara aktivitas fisik dengan menyebabkan kanker paru-paru dan sistem kejadian $\mathrm{dm}$ Tipe 2. Diperoleh nilai $\mathrm{OR}=$ saluran pernapasan lainnya. Rokok juga 1,9 yang artinya seseorang dengan pola membawa dampak pada peningkatan kadar makan tidak seimbang memiliki risiko 2 kali kolesterol jahat dan trigliserida (Waris, lebih besar menderita DM tipe 2 2015).

dibandingkan dengan orang dengan pola makan seimbang.

Kesimpulan untuk pengaruh pola makan terhadap kejadian DM tipe 2 dari hasil penelitian ini dan didukung oleh penelitian lainnya yang bahwa pola makan mempengaruhi kejadian DM tipe 2.

Peneliti berasumsi meskipun dalam penelitian ini tidak ada hubungan antara kebiasaan merokok dengan kejadian DM tipe 2, akan tetapi peneliti sependapat dengan toeri bahwa seseorang yang merokok akan lebih besar kemungkinan menderita DM tipe 2 dibandingan dengan Pengaruh Kebiasaan Merokok Terhadap seseorang yang tidak merokok, karna Kejadian DM tipe 2

Berdasarkan

\section{hasil} pengaruh nikotin yang dikandung rokok sangat kebiasaan merokok terhadap kejadian DM tipe 2 bahwa responden yang merokok proporsinya pada kasus yaitu $34,0 \%$ dan kelompok kontrol 28,4\%. Beda proporsi antara kasus dan kontrol sebesar 5,6\%. Hasil uji Chi-Square didapatkan $p$ value $=0,337$. Karena $0,337>0,05$ maka beda proporsi tersebut tidak bermakna, yang artinya tidak membahayakan kesehatan seseorang.

Hasil penelitian ini bertentangan dengan penelitian Radio Putro (2011). Hasil penelitiannya menunjukan ada hubungan antara kebiasaan meokok dengan kejadian $\mathrm{dm}$ Tipe 2 dengan $\mathrm{OR}=2,8$ yang artinya orang merokok memiliki risiko 2,8 kali lebih besar menderita DM tipe 2 dibandingkan dengan orang yang tidak merokok. 
Bertentangan juga dengan hasil bermakna, yang artinya ada pengaruh penelitan Penelitian Shara Kurnia dan obesitas terhadap kejadian DM tipe 2.

Soedijono Setyorogo (2013). Hasil Hasil perhitungan OR 95\% CI = penelitiannya juga menunjukan ada 2,622 (1,660-4,140) yang artinya responden hubungan antara kebiasaan meokok dengan yang kegemukan berpeluang 2,6 kali kejadian dm Tipe 2. Diperoleh nilai OR = menderita DM tipe 2 dibanding kontrol.

3,4 yang artinya seseorang yang merokok Sebagian besar kelompok kasus memiliki risiko 3,4 kali lebih besar adalah obesitas atau IMT $\geq 27 \mathrm{~kg} / \mathrm{m}^{2}$. menderita DM tipe 2 dibandingkan dengan Sehingga peneliti berasumsi bahwa obesitas orang yang tidak merokok.

Bertentangan juga dengan hasil menyebabkan seseorang menderita DM tipe penelitan Penelitian Wahyu Ratri (2016). 2, hal ini disebabkan karna jika lemak Hasil penelitiannya juga menunjukan ada menumpuk didalam tubuh maka maka kadar hubungan antara kebiasaan meokok dengan gula didalam tubuh akan semakin tinggi. kejadian dm Tipe 2. Diperoleh nilai OR $=$ Hal ini didukung oleh teori yang 2,5 yang artinya seseorang yang merokok menyebutkan obesitas terjadi akibat memiliki risiko 2,5 kali lebih besar ketidakseimbangan masukan dan keluaran menderita DM tipe 2 dibandingkan dengan kalori dari tubuh serta penurunan aktifitas orang yang tidak merokok.

Bertentangan juga dengan hasil menyebabkan penumpukan lemak di penelitan Penelitian Zuheri (2014). Hasil sejumlah bagian tubuh (Rosen, 2008).

penelitiannya juga menunjukan ada Obesitas menunjukkan adanya hubungan antara kebiasaan meokok dengan penumpukan lemak yang berlebihan di kejadian dm Tipe 2. Diperoleh nilai OR = dalam tubuh, ditandai dengan peningkatan 2,7 yang artinya seseorang yang merokok nilai masa indeks tubuh di atas normal, memiliki risiko 2,7 kali lebih besar orang yang mengalami penumpukan lemak menderita DM tipe 2 dibandingkan dengan yang lebih banyak dalam jangka waktu yang orang yang tidak merokok.

Kesimpulan untuk pengaruh lama akan menjadi risiko tinggi DM, kebiasaan merokok terhadap kejadian DM tipe 2 dari hasil penelitian ini menunjukan tidak ada pengaruh kebiasaan merokok terhadap kejadian DM tipe 2, berbeda dengan hasil penelitian yang dilakukan oleh peneltiti sebelumnya, hal ini disebabkan karna penelitian ini teknik sampling yang digunakan dalam penelitian ini adalah purposive sampling dan kuseioner yang peneliti gunakan hanya secara garis besar saja.

\section{Pengaruh Obesitas Terhadap Kejadian DM tipe 2}

Kemenkes RI (2011).

Penelitian Miftahul Adnan, Dkk (2013) tentang Hubungan Indeks Massa Tubuh (IMT) dengan kadar gula darah penderita DM tipe 2 menunjukkan bahwa ada hubungan antara IMT dengan kadar gula darah penderita DM tipe 2. Semakin tinggi nilai IMT semakin tinggi pula kadar gula darahnya. Demikian pula dengan hasil penelitian Shara \& Setyorogo (2013), menunjukkan adanya pengaruh IMT terhadap DM.

Penelitian yang dilakukan Liu Liya, et al (2013) di Cina meunjukan hal yang Berdasarkan hasil pengaruh obesitas sama. Dari hasil penelitiannya diperoleh terhadap kejadian DM tipe 2 bahwa nilai OR sebesar 2,0 yang artinya orang responden yang kegemukan proporsinya yang obesitas memiliki peluang menderita pada kasus yaitu 52,5\% dan kelompok DM tipe 22 kali lebih besar dibandingkan kontrol 29,6\%. Beda proporsi antara kasus dengan orang yang tidak obesitas.

dan kontrol sebesar 22,9\%. Hasil uji Chi-

Penelitian yang dilakukan Niciane Square didapatkan $p$ value $=0,000$. Karena Bandeira (2013) di Brazil meunjukan hal $0,000<0,05$ maka beda proporsi tersebut yang sama. Dari hasil penelitiannya diperoleh nilai OR sebesar 4,2 yang artinya 
orang yang obesitas memiliki peluang menderita DM tipe 2 4,2 kali lebih besar dibandingkan dengan orang yang tidak obesitas.

Sejalan juga dengan hasil penelitian Kaban (2007), dari hasil penelitiannya diperoleh nilai OR sebesar 4,6 yang artinya orang yang obesitas memiliki peluang menderita DM tipe 2 4,6 kali lebih besar dibandingkan dengan orang yang tidak obesitas.

Kesimpulan untuk pengaruh obesitas terhadap kejadian DM tipe 2 dari hasil penelitian ini dan didukung oleh penelitian lainnya yang bahwa terdapat pengaruh obesitas terhadap kejadian DM tipe 2.

Faktor Yang Berpengaruh Terhadap Kejadian DM Tipe 2

Dari hasil analisis multivariat, 2 didapatkan 4 variabel yang berpngaruh terhadap kejadian DM tipe 2, yaitu umur, aktivitas fisik, pola makan dan obesiatas. Aktivitas fisik merupakan faktor yang paling berpengaruh terhadap kejadain DM tipe 2 di di poliklinik penyakit dalam RSPAD Gatot Subroto Jakarta Pusat Tahun 2017 dengan $\mathrm{p}$ value $0,000(\mathrm{p}<0,05)$ dan OR 4,727 yang artinya orang yang aktivias fisiknya kurang berpeluang 4,7 kali menderita DM tipe 2 dari pada orang yang aktivitas fisikya cukup setelah di kontrol variabel umur, pola makan dan obesitas. Dari 162 responden kelompok kasus terdapat $125(77,2 \%)$ responden dengan aktivitas fisik kurang. Sebagian besar responden yang menderita DM tipe 2 adalah orang dengan aktivitas fisik kurang, hal ini membuktikan kalau aktivitasfisik kurang mempengaruhi kejadian DM tipe 2.

Peneliti berasumsi bahwa pola hidup yang tidak sehat seperti kurangnya aktivitas fisik, maka risiko menderita DM tipe 2 lebih tinggi, hal ini disebabkan karna dengan melakukan aktivitas fisik 30 sehari yang dilakukan terus menerus akan menyebabkan pembakarakan lemak dengan cara menguba glukosa menjadi energi. Seperti yang diketauhi bahwa dari beberapa penelitian sebelumnya kalau aktivitas fisik memang erat hubungannya dengan peyait DM tipe 2 ,
bukan hanya menyebabkan DM tipe 2 , kurangnya aktivitas fisik juga dapat menyebabkan terjadinya penyakit tidak menular lainnya, seperti penyakit kardiovaskuler dan stroke.

Berdasarkan fatofisiologinya dengan kurang melakukan aktivitas fisik maka zat makanan yang masuk kedalam tubuh tidak dibakar tetapi ditimbun dalam tubuh sebagai lemak dan gula. Jika insulin tidak mencukupi untuk mengubah glukosa menjadi energi maka akan timbul DM (Betteng, 2014).

Jika seseorang yang masih berumur mudah, tidak memiliki riwayat DM dalam keluarga, pola makan seimbang dan juga tidak obesitas, akan tetapi tidak melakukan aktivitas fisik yang cukup, maka orang tersebut masih berisiko menderita DM tipe 2.

Intervensi gaya hidup kita adalah sistematis dan intensif, dengan peserta studi menerima rinci, konseling individual. Penelitian ini, bagaimanapun, tidak dirancang untuk menguji kontribusi relatif dari perubahan pola makan, meningkatkan aktivitas fisik, dan penurunan berat badan untuk pengurangan risiko diabetes.

Seiring dengan perkembangan ekonomi dan perubahan menuju gaya hidup yang tidak memiliki aktivitas fisik dan kaya diet tinggi lemak, prevalensi diabetes meningkat. Oleh karena itu, adalah penting bahwa program pendidikan kesehatan terpadu di masyarakat agar meningkatkan kesadaran masyarakat tentang DM tipe 2 (Shugang Li et all, 2015).

Hasil penelitian ini sejalan dengan penelitian yang dilakukan Radio Putro (2011), yang menunjukan kalau aktivitas fisik merupakan variabel yang paling berhubungan dengan kejadaian DM tipe 2 di Poliklinik Penyakit Dalam Rumah Sakit Dr. Kariadi, dengan nilai OR yang diperoleh sebesar 3,0, yang artinya orang dengan aktivitas fisik kurang memiliki risiko 3,0 kali lebih besar menderita DM tipe 2 dibandingkan dengan orang dengan aktivitas fisik cukup.

Meskipun menggunakan desain penelitian yang sama dengan peneliti sebelumnya akan tetapi keunggulan 
penelitian ini adalah besar nilai OR yang diperoleh dalam penelitian ini lebih besar dibandingkan dengan penelitian sebelumnya.

\section{Pengaruh Pendidikan dan Riwayat DM Terhadap Gaya Hidup}

Berdasarkan hasil analisis bivariat variabel yang tidak berpengaruh terhadap DM tipe 2 adalah pendidikan, riwayat DM , kemudian dilakukan analisis lebih lanjut untuk melihat variabel pendidikan dan riwayat DM apakah mempengaruhi gaya hidup responden yaitu pola makan dan aktivitas fisik. Setelah dilakukan analisis pengaruh pendidikan dan riwayat DM terhadap pola makan, hasil statistik menunjukan bahwa tidak ada pengaruh pendidikan terhadap pola makan, karna diperoleh nilai $\mathrm{p}$ value sebesar 0,158 dan tidak ada pengaruh riwayat DM terhadap pola makan, karna diperoleh nilai $\mathrm{p}$ value sebesar 0,88 .

Kemudian dilakukan analisis pengaruh pendidikan dan riwayat DM terhadap aktivitas fisik, hasil statistik menunjukan bahwa tidak ada pengaruh pendidikan terhadap aktivitas fisik, karna diperoleh nilai $\mathrm{p}$ value sebesar 0,080 dan tidak ada pengaruh riwayat DM terhadap aktivitas fisik, karna diperoleh nilai $\mathrm{p}$ value sebesar 0,80 .

Hasil ini cukup membuktikan bahwa meskipun seseorang yang berpendidikan tinggi akan tetap menderita DM tipe 2 apabila pola makannya tidak seimbang dan aktivitas fisiknya kurang. Seseorang yang tidak memiliki riwayat DM akan tetap menderita DM tipe 2 apabila pola makannya tidak seimbang dan aktivitas fisiknya kurang.

\section{Penutup}

\section{Kesimpulan}

1. Variabel yang berpengaruh terhadap kejadian DM tipe 2 adalah umur $(\mathrm{p}=0,000)$, jenis kelamin $(\mathrm{p}=0,011)$, aktivitas fisik $(\mathrm{p}=0,000)$, pola makan $(\mathrm{p}=0,001)$ dan obesitas $(\mathrm{p}=0,000)$.

2. Variabel yang tidak berpengaruh terhadap dengan kejadian DM tipe 2 adalah pendidikan, riwayat $\mathrm{DM}$ dan kebiasaan merokok.

3. Variabel yang pasling berpengaruh terhadap DM tipe 2 adalah aktivitas fisik, orang yang aktivias fisiknya kurang berpeluang 4,7 kali menderita DM tipe 2 dari pada orang yang aktivitas fisiknya cukup setelah di kontrol variabel umur, pola makan dan obesitas.

4. Tingginya kejadian DM tipe 2 Di RSPAD Gatot Subroto Jakarta Pusat salah satunya disebabkan karena pasien DM tipe 2 kurang melakukan aktivitas fisik, rata2 pasien hanya melakukan aktivitas yang hanya mengerjakan pekerjaan rumah tangga saja. Selain itu juga disebabkan karena pola makan pasien yang tinggi kabrohidrat dan rendah serat.

\section{Saran}

\section{Untuk RSPAD Gatot Subroto}

a. Disarankan untuk melakukan deteksi dini penyakit tidak menular (PTM) dan juga promosi kesehatan tentang penyakit DM tipe 2, dan beberapa faktor risiko yang berhubungan dengan penyakit DM tipe 2 seperti melakukan aktivitas fisik yang cukup dan pola makan yang seimbang.

b. Disarankan untuk memberikan promosi kesehatan melalui siaran TV lokal yang sudah ada dilingkungan RS PAD sehingga pengunjung mendapatkan informasi tentang pentingnya olahraga dan menjaga pola makan yang sehat dalam mencegah penyakit DM tipe 2

c. Mengaktifkan club senam Diabetes yang diselenggarakan Oleh tim edukasi Diabetes RSPAD sehingga memberi kesempatan bagi masyarakat yang berkunjung ke RSPAD untuk melakukan senam.

d. Menganjurkan pasien yg obase untuk konsultasi gizi, untuk mendapatkan gizi yang seimbang

\section{Untuk Masyarakat}

a. Disarankan juga, agar melakukan pemeriksaan gula darah secara periodik pada masyarakat yang 
berumur $>40$ tahun terutama pada perempuan untuk deteksi dini penyakit tidak menular seperti DM tipe2

b. Diharapkan untuk selalu melakukan aktivitas fisik yang cukup dengan cara melakukan latihan fisik sedang atau berat, selama 30 menit atau lebih secara terus menerus dan dilakukan seminggu 3 kali (selang sehari).

c. Diharapkan untuk menjaga pola makan yang baik seperti konsumsi rendah gula dan tinggi serat (lebih banyak makan buah dan sayuran) maka dapat memperkecil risiko menderita DM tipe 2.

d. Dan juga menjaga IMT (berat badan) tetap normal dengan cara menjaga pola makan yang seimbang, karena obesitas terjadi akibat ketidakseimbangan masukan dan keluaran kalori dari tubuh serta penurunan aktifitas fisik (sedentary life style) yang menyebabkan penumpukan lemak di sejumlah bagian tubuh

\section{Untuk Peneliti selanjutnya}

a. Diharapkan pada peneliti lain untuk dapat mengembangkan dan melanjutkan penelitian ini dengan menggunakan teknik dan instrument yang lain agar dapat mengkaji aspekaspek yang berkaitan dengan faktorfaktor lain yang berhubungan dengan penyakit DM tipe 2.

b. Untuk variabel merokok disarankan untuk peneliti supaya sebelumnya melakukan pertanyaan yang lebih mendalam dan juga menggunakan teknik random sampling.

\section{Daftar Pustaka}

[1] American Diabetes Association, 2011. Standards of Medical Care for Patients With Diabetes Mellitus, Diabetes Care. USA.

[2] Anne, 2010. Gaya Hidup Sehat. Bandung: Graha Indah Buana

[3] Ario Dwi, 2014. Effect Of Nicotine In Cigarette For Type 2 Diabetes Mellitus. Artikel Review. J Majoity Vol.3, No.7
[4] Azwar. 2010. Pengantar Administrasi Kesehatan. ed ke-3 Tangerang Binarupa Aksara Publiher

[5] Betteng R., Pangemanan D \& Mayulu N. 2014. Analisis Faktor Risiko Penyebab Terjadinya Diabetes Mellitus Tipe 2 Pada Wanita Usia Produktif di Puseksmas Wanonasa. Jurnal $e$ Biomedik (Ebm), Vol.2, No.2

[6] Bisma Murti, 2003. Prinsip Dan Metode Riset Epidemiologi. Yogyakarta: Gajah Mada University Press

[7] Buchari Lapau, 2015. Metode Penelitian Kesehatan: Metode Ilmiah Penulisan Skripsi, Tesis dan Disertasi. Jakarta: Yayasan Pustaka Obor Indonesia

[8] Bustan. 2007. Epidemiologi Penyakit Tidak Menular. Jakarta: Rineka Cipta

[9] Codario, R.A., 2005. Pathophysiology of Type 2 Diabetes. In Skolnik, N.S. ed. Type 2 DM, Type 2 Diabetes, Prediabetes and The Metabolic Syndrome. New Jersey: Humana Press, $1-12$

[10] Depkes, RI., 2008. Pedoman Umum Gizi Seimbang. Jakarta: Ditjen Pembinaan Kesehatan Masyarakat. Direktorat Bina Gizi Masyarakat. Jakarta

[11] Deby Marlina, 2015. Pengaruh Pola Makan dan Aktivitas Fisik Terhadap Kejadian Diabetes Melitus Tipe 2 di RSUD Dr. Pringadi Kota Medan Tahun 2015. Program Studi S2 Kesehatan Masyarakat, Universitas Sumatra Utara

[12] Ferdinan, Augusty, 2006. Sructural Equation Modeling dalam Penelitian Manajemen, Aplikasi Model-Model Rumit dalam Penelitian untuk Tesis Magister dan Desertasi Doctor, Badan Penerbit Uiversitas Diponegoro.

[13] Hardani Rika, 2002. Pola Makan Sehat. Makalah Seminar Online Kharisma ke 2 Yogyakarta RS Dr. Sudjito

[14] Hidayat, A. Aziz Alimul. 2007. Metode Penelitian Keperawatan dan Teknik Analisa Data. Jakarta : Salemba Medika. 
[15] Kaban, Sempakata, 2007. Diabetes Tipe 2 di Kota Sibolga Tahun 2005. Majalah Kedokteran Nusantara. Volume 40 No 2 Juni 2007.

[16] Kotler P., 2002. Manajemen pemasaran. Edisi Millenium. Jakarta : Prenhallindo

[17] Lemeshow, Stanley. 1997, Adequacy Of Sample Size In Health Studies, World Health Organization

[18] Liu L., Chen L., Dai J., Liang., Pei T \& Huang Y. 2013. Effect of green tea on glucose control and insulin sensitivity: a meta-analysis of 17 randomized controlled trials. Am J Clin Nutr 98 (2):340-8. doi: 10.3945/ ajen.112.052746

[19] Luping W., Takuhiro Y., Toshiko Y., Akane K., Kazuko S \& Yasuo O. 2002. A Case-Control Study of Risk Factors for Development of Type 2 Diabetes: Emphasis on Physical Activity. Journal of Epidemiology Vol, 12, No. 6 November

[20] Miftahul A., Tatik M \& Joko TI. 2013. Hubungan Indeks Massa Tubuh (IMT) dengan Kadar Gula Darah Penderita Diabetes (DM) Tipe 2 Rawat Jalan Di RS Tugurejo Semarang. Jurnal Gizi Universitas Muhamadiyah Semarang. Vo.2, No, 1

[21] Munawar. 2014. Pengaruh Obesitas, Aktifitas Fisik, Merokok, Riwayat Keluarga Terhadap Kejadian Diabetes Pada Usia < 45 Tahun Di Kota Lhokseumawe. Program Studi S2 Ilmu Kesehatan Masyarakat Universitas Sumatera Utara

[22] Niciane B., Ana M., Paulo C \&Marta M. Risk for type 2 diabetes mellitus and associated factors (Risco para diabetes mellitus tipo 2 e fatores associados). Acta Paul Enferm. 2013; 26(6):569-74

[23] Nurlaili \& Muhamad, 2013. Hubungan Empat Pilar Pengendalian DM Tipe 2 dengan Rerata Kadar Gula Darah. Departemen Epidemiologi FKM UA. Universitas Erlangga

[24] Nursalam, 2003. Konsep dan Penerapan Metodologi Ilmu Keperawatan: Pedoman Skrpsi, Tesis dan Instrument Penelitian

Keperawatan. Jakarta: Salemba

Medika.

[25] Norman B Anderson, 2004. Encyclopedia of Health and Behavior 1. California: Sage publication

[26] Notoatmodjo. S. 2010. Metodologi Penelitian Kesehatan. Jakarta: Rineka Cipta

[27] PERKENI, 2011. Konsensus Pengolahan dan Pencegahan Diabetes Melitus Tipe 2 di Indonesia. http;//Evluation Management. com. published 9 Feb 2013

[28] Prihaningtyas, R, A. 2013. Hidup Manis dengan Diabetes. Yogyakarta : Media Pressindo

[29] Radio Putro, 2011. Faktor-Faktor Yang Behubungan dengan Kejadian DM Tipe 2 (Studi Kasus di Poliklinik Penyakit Dalam Rumah Sakit Dr. Kariadi). Fakultas Kedokteran, Universitas Diponogoro.

[30] Riskesdas, 2013. Pengaruh Gaya Hidup terhadap Kejadian Diabetes Mellitus pada Masyarakat di Provinsi Sulawesi Selatan. Pusat Teknologi Kesehatan Masyarakat Badan Penelitian dan Pengembangan Kesehatan Kemenkes RI 2014

[31] Rudy Bilos \& Ricard, 2014. Buku Pegangan Diabetes Edisi Ke-4. Jakarta: Buni Medika

[32] Shara Kurnia Trisnawati dan Soedijono Setyorogo, 2013. "Faktor Risiko Kejadian Diabetes Melitas Type II di Puskesmas Kecamatan Cengkareng Jakarta Barat Tahun 2012”, Jurnal Ilmiah Kesehatan, Vol.5, No.1

[33] Sherwood, L. 2012. Fisiologi Manusia dari Sel ke Sistem. Edisi 6. Jakarta : EGC

[34] Sluik D., Boeing H., Li K., Kaaks R., Johnsen NF., Tjonneland A., Arriola L., Barricarte A., Masala G., Grioni S., Tumino R., Ricceri F., Mattiello A., Spijkerman AM., Van Der A Dl., Sluijs I., Franks PW., Nilsson PM., OrhoM., Fharm E., Rolandsson O., Riboli E., Romaguera $\quad$ D., Weiderpass 
E., Sánchez CE \& Nothlings U. 2013. Lifestyle Factors and Mortality Risk In Individual with Diabetes Mellitus: Are The Associations Different From Thoes In Individual Without Diabetes? [on line]. Dari: http://www.ncbi.nlm.nih. gov/ pubmed/24132780

[35] Sudaryanto A., Noor AS \& Diah AF. 2014. Hubungan Pola Makan, Genetik dan Kebiasaan Olahraga Terhadap Kejadian Diabetes Melitus Tipe 2 di Wilayah Kerja Puskesmas Nusukan, Banjarsari. Fakultas Teknik Universitas Wahid Hasyim Semarang. ISBN 978-602-99334-3-7

[36] Sugiyono, 2007. Metode Penelitian Bisnis. Cetakan Kesembilan Bandung: CV Alfabeta

[37] Soegondo Sidartawan. 2007. Penatalaksanaan Diabetes Melitus Terpadu. Jakarta: FKUI

[38] Soewondo, Pradana, dan Laurentius A. Pramono, 2011. "Prevalence, Characteristics, and Predictors of Prediabetes in Indonesia", Medicine Journal Indonesia, Vol.20, No.4, November 2011

[39] Sunita Almatsier, 2006. Penuntun Diet. Jakarta: Gramedia Pustaka Utama

[40] Sumanth M., Bala S., Gautam R \& Ashok KD. 2012. Risk Factors of Diabetes Mellitus in Rural Puducherry. Online Journal of Health and Allied Sciences. Mangalore, South India : ISSN 0972-5997: Volume 11, Issue 1; Jan-Mar 2012

[41] Susilo Yeki \& Ari Wulandari, 2011. Cara Jitu Mengatasi Diabetes Mellitus (Kencing Manis). Yogyakarta: C.V Andi

[42] Sutanto Priyo Hastomo, 2016. Analisis Data pada Bidang Kesehatan. Jakarta: Raja Grafindo Persada

[43] Shugang L., Shuxia G., Fei H., Mei Z., Jia He, Yizhong Y., Yusong D., Jingyu Z., Jiaming L., Heng G., Shangzhi X \& Rulin M. Prevalence of Diabetes Mellitus and Impaired Fasting Glucose, Associated with Risk Factors in Rural Kazakh Adults in Xinjiang, China. Int. J. Environ. Res. Public Health 2015,
12 , 554-565; doi:10.3390/ijerph120100554

[44] Stacey, Rosen. 2008. Obesity in The Midst of Unyielding Food Insecurity in Developing Countries. Amber Waves. Vol 6. Issue 4

[45] Tandra, H., 2014. Strategi Mengalahkan Komplikasi Diabetes dari Kepala sampai Kaki. Jakarta: Gramedia Pustaka Utama

[46] Taylor Barbara, 2009. Diabetes Tak Bikin Lemes. Yogyakarta: Paradigma Indonesia

[47] Trisnawati Sri., Tangking W \& Ketut S. 2013. Faktor Risiko Diabetes Melitus Pasien Rawat Jalan Di Puskesmas Wilayah Kecamatan Denpasar Selatan. Publich Heath and Preventive Medicine Achtive, Vol.1, No.1

[48] Valentine, RJ., Vieira, VJ., Woods, Jeffrey A \& Evans E. 2009. Stronger Relationship Between Central Adiposity And $C$ Reactive Protein In Older Women Tahn Men'. Source Menopause: 16, 84-89

[49] Wahyu Ratri, 2016. Faktor Risiko Kejadian DM Tipe 2 Di Wilayah Kerja Puskesmas Purwadiningratan Surakarta. Fakultas Kesehatan Masyarakat, Universitas Muhamadya Surakarta.

[50] Waris Marewa Lukman, 2015. Kencing Manis (Diabetes Mellitus) Di Sulawesi Selatan. Jakarta: Yayasan Puskata Obor Indonesia.

[51] Zahtamal., Fifia C., Suyanto \& Tuti. 2007. "Faktor-faktor Risiko Pasien Diabetes Melitus" dalam Berita Kedokteran Masyarakat. Vol.23 No.3 September 2007

[52]Zuheri, 2014. Faktor Risiko yang Memengaruhi Kasus Penderita Diabetes Melitus di Wilayah Kerja Puskesmas Banda Sakti Kecamatan Banda Sakti Kota Lhokseumawe Tahun 2014. Program Studi S2 Ilmu Kesehatan Masyarakat Universitas Sumatera Utara. 